\title{
A procedure to evaluate the most suitable integrated solutions for increasing energy performance of the building's envelope, avoiding moisture problems
}

\author{
Anna Magrini ${ }^{1 *}$, Stefano Lazzari ${ }^{2}$, Ludovica Marenco ${ }^{3}$, Giulia Guazzi ${ }^{4}$ \\ ${ }^{1}$ Dept. Civil Engineering and Architecture, University of Pavia, Via Adolfo Ferrata, Pavia 127100, \\ Italy \\ 2 Dept. Architecture and Design, University of Genova, Stradone S. Agostino, Genova 3716123, Italy \\ ${ }^{3}$ IRE S.p.A. (Infrastrutture Recupero Energia), Via XX Settembre, Genova 4116121, Italy \\ ${ }^{4}$ ITC-CNR, Construction Technologies Institute - Italian National Research Council, San Giuliano \\ Milanese, MI, Italy
}

Email: magrini@unipv.it

\begin{abstract}
General guides to support the refurbishment design indicate separately the solutions to common problems such as thermal loss, interstitial condensation, sound transmission, fire safety etc. This paper deals with combined solutions that take into account simultaneously two of these aspects, aiming both at reducing thermal losses and at avoiding or limiting problems related to moisture transfer and condensation, jointly with an indispensable cost analysis. Improving the energy performance of buildings should start from the evaluation of the building's envelope energysaving options.

The subject of the research is oriented to typical buildings, often critical from the energy standpoint, which are represented by social housings. The refurbishment target should be the NZEB model, even if it is very difficult to find suitable general solutions. As the renovation design process depends also on the sustainability of costs, an evaluation procedure, previously proposed, is widened to take into account this aspect, by considering characteristics and constraints, and assuring reasonable costs for the most suitable solutions.

The methodology has been applied to a case study represented by a common building unit. The insulation improvement is made through a choice of the most suitable combination of material and thickness, with the aim not only of the energy saving, but also of the reduction of the risk of vapour condensation that depends, among other things, on the position of the insulating materials within the wall's structure. Some combined refurbishment solutions for the building envelope are examined and the corresponding costs are evaluated. Moreover, to show the importance of the problem in mild and continental climates, a comparison of the results in different climatic conditions is presented.
\end{abstract}

Keywords: EPBD, Energy Performance, Vapour Condensation Risk, Cost Analysis, Building Refurbishment.

\section{INTRODUCTION}

Minimum energy performance requirements are indicated by the European Commission both to reach NZEB standard by the year 2019 (new public buildings) and 2021 (all new buildings) [1] and to reduce the energy consumption in case of building refurbishment, aiming at the NZEB model.

The EPBD (2010) application has led to define Guidelines on a comparative methodology framework for calculating cost-optimal levels [2] for buildings and building elements.

To improve energy performance of building envelope elements (art.4, [1]), additional insulation systems are indicated, taking into account the maximum allowable thickness for each building element. The Guidelines entrust the National Governments to establish limiting U-values (thermal transmittance). Particular attention has to be paid in considering the climatic context and for avoiding critical surface humidity and interstitial condensation.

The building retrofit towards NZEB represents a big challenge of the next future, and an essential purpose of the EPBD, demonstrated also by the number of European Projects financed by the EU Commission on this topic.

For instance, the following EU Projects give useful indications about the most suitable approach to follow:

- $\quad$ ENTRANZE (policies to ENforce the TRAnsition to $\mathrm{NZEb}$ ), indicates the way to achieve a fast and strong penetration of NZEB within the existing national building stocks, supporting policy making by providing data, analyses and guidelines;

- REPUBLIC ZEB (REfurbishment of the PUBLIC building stock towards nZEB), focuses the attention on the way to refurbish the existing public building stock towards 
Nearly Zero-Energy Buildings, in the South-Eastern European countries;

- $\quad$ RESHAPE (REtrofitting Social Housing and Active Preparation for EPBD) organizes strategies for retrofitting supporting housing managers to propose them to tenants, apartment owners and housing cooperatives.

Several studies on suitable solutions for the energy performance retrofit towards the class A or NZEB are available, to highlight the most suitable interventions [3]. However, the highest interest focuses on the combination between these indications and the economic aspects. This represents a more complex topic even if fundamental in the energy retrofitting, aimed at leading towards zero carbon emission. This aspect is presented as a socio-economical action towards NZEB in [4].

The investigation on the most suitable solutions, economically sustainable, starts from the interest on existing buildings, like the one supported by INVESTIMMO project, proposing a decision-making tool for long-term efficient investment strategies in housing maintenance and refurbishment. In recent times the TABULA project (Typology Approach for Building Stock Energy Assessment) has given a classification scheme, grouping buildings according to their size, age and further parameters, and defined a set of exemplary buildings representing building types.

It was followed by the EU project EPISCOPE, focused on retrofitting of existing single-family house typology, from which analyses on refurbishment scenarios to achieve NZEB [5] were developed.

In the building retrofit towards NZEB, the thermal insulation plays a central role for the reduction of thermal energy-needs of the building envelope.

The insulating solutions (on the external or internal face of the walls or in the air gap, if present) are effective even if some technical difficulties can be met for the façade complexity or articulation, for the significant reduction of the internal volume, depending on both the thermo-physical properties and the thickness of the materials adopted.

However, among other important aspects that should be considered to adopt the most suitable solutions, the risk of vapour condensation may represent a relevant factor to direct properly the restoration design.

The use of an integrated methodology could support the most suitable choice, taking into account aspects that influence directly or indirectly each other, which are equally important in the whole project but often are considered separately.

The renovation actions on existing buildings (opaque envelope) should be optimized taking into account jointly constraints and assessments about, for example, the following aspects:

- $\quad$ sustainable choice of materials;

- LCA;

- $\quad$ summer energy performance;

- $\quad$ seismic risk;

- fire protection;

- acoustic insulation;

- global economic evaluation of the retrofit actions.

Multicriteria analyses could lead to an optimal integrated design and could be very useful to support designers and technicians' decisions. Some studies propose multicriteria analyses, focalized to the building energy-efficiency improving, considering contemporarily a great number of variables [6]. In particular, focusing on envelope elements, it is important to take into account also sustainability protocols recommendations [7].

The subject of the present research is oriented to social housings, buildings typically critical from the energy standpoint. The refurbishment target should be represented by the NZEB model, focusing the attention on the relation between thermal insulation improvement and vapour condensation risk. The two aspects must be evaluated also for their cost sustainability.

An evaluation procedure, previously proposed [8], is applied to a case study represented by a common building unit located at an intermediate floor of a tall building.

Two typical existing walls, representative of social housing building envelope in some EU countries, are analysed, referring to their $U$-value (thermal transmittance) and its reduction to reach the NZEB limits.

The aim is not only the insulation improvement, through the choice of the most suitable combination of materials and thicknesses, but also the reduction of the vapour condensation risk that depends on the thermophysical properties, the position of the insulating materials within the wall's structure and the outdoor climatic conditions.

Moreover, as the renovation design process depends on the costs sustainability, the procedure is widened to take into account also this aspect, considering characteristics and constraints to guarantee the most suitable solution with acceptable costs.

The case study is intended to show the relevance of the problem in the Mediterranean area and not only in the colder climates of the northern EU regions. To this aim, the climatic conditions of two countries have been considered, located on the coast and in the continental regions of Italy and France.

Therefore, the energy performance of the case study is calculated, some improvement solutions are proposed, in terms of U-value reduction by insulation, the corresponding costs are considered. The first series of results are referred to continental climatic conditions of an Italian town to test the procedure application. The second series of results compare two locations in the same country to show the differences in reaching NZEB target and vapour condensation problems with the same national laws, rules and limiting values. The third series of results focuses the attention on differences between climatic conditions of two countries.

\section{METHODOLOGY}

\subsection{Energy performance assessment}

The European Standards elaborated under the $M / 480$ Mandate [9] give indications on the methodology for the energy performance assessment. As summarised in [10], the EN ISO 13790 Standard [11] provides the main indications on the calculation methods for the design and evaluation of thermal and energy performance of buildings.

In the present analysis, the attention has been focused on the following main parameters:

- $\quad$ the opaque wall thermal transmittance U;

- the $\mathrm{EP}_{\mathrm{H}, \mathrm{env}}$, such as the ratio between the building energy need for continuous heating $\mathrm{Q}_{\mathrm{H}, \mathrm{nd}}$ and the net surface area $\mathrm{A}_{\mathrm{f}}$ :

For the first one, some countries indicate different limiting values related to the NZEBs and the refurbishment. Generally, 
the energy improvement actions are directed to reduce its values, for example, by placing a layer of insulating material.

The second parameter, $\mathrm{Q}_{\mathrm{H} \text {,nd }}$, depends not only on the $\mathrm{U}$ values but also on the climatic conditions (extra-flux, solar radiation) and on the wall thermal capacity. Its value, divided by the net surface area $A_{f}$ allows to calculate the energy need

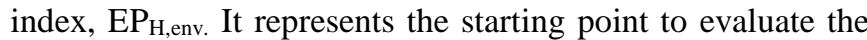
primary energy index $\mathrm{EP}_{\mathrm{H}}$, which is subjected to national limits in some countries, referring to the NZEBs or to the refurbishment.

As indicated in [11], the energy need $\mathrm{Q}_{\mathrm{H}, \mathrm{nd}}$ can be calculated by:

$$
\mathrm{Q}_{\mathrm{H}, \text { nd }}=\left(\mathrm{Q}_{\mathrm{tr}}+\mathrm{Q}_{\mathrm{ve}}\right)-\eta_{\mathrm{H}, \mathrm{gn}}\left(\mathrm{Q}_{\mathrm{int}}+\mathrm{Q}_{\mathrm{sol}}\right)
$$

where:

- $\mathrm{Q}_{\text {tr }}$ is the total heat transfer by transmission $[\mathrm{MJ}]$;

- $\mathrm{Q}_{\mathrm{ve}}$ is the total heat transfer by ventilation $[\mathrm{MJ}]$;

- $\mathrm{Q}_{\text {int }}$ is the sum of internal heat gains $[\mathrm{MJ}]$;

- $\mathrm{Q}_{\text {sol }}$ is the sum of solar heat gains over the given period $[\mathrm{MJ}]$;

- $\quad \eta_{\mathrm{H}, \mathrm{gn}}$ is the dimensionless gain utilization factor [-].

The calculations can be performed on the basis of monthly mean climatic data. The U-value is important to define the contribution of $\mathrm{Q}_{\mathrm{tr}}$, that is expressed as follows:

$\mathrm{Q}_{\mathrm{tr}}=\mathrm{H}_{\mathrm{tr}}\left(\theta_{\mathrm{i}}-\theta_{\mathrm{e}}\right) \mathrm{t} \quad[\mathrm{MJ}]$

where:

- $\left(\theta_{\mathrm{i}}-\theta_{\mathrm{e}}\right)$ is the monthly mean temperature difference between indoor and outdoor environment $\left[{ }^{\circ} \mathrm{C}\right]$

- $\mathrm{t}$ is the heating or cooling time period [s]

- $\mathrm{H}_{\mathrm{tr}}$ is the overall heat transfer coefficient by transmission, determined by:

$$
\mathrm{H}_{\mathrm{tr}}=\Sigma_{\mathrm{i}} \mathrm{H}_{\mathrm{x}, \mathrm{i}} \quad\left[\mathrm{W} \mathrm{K}^{-1}\right]
$$

with $\mathrm{H}_{\mathrm{x}}$ representing the heat transfer coefficient of transmission to the external environment, $H_{D}$, to the ground, $\mathrm{H}_{\mathrm{g}}$, to adjacent zones, maintained at different temperatures, $\mathrm{H}_{\mathrm{A}}$, or unconditioned zones, $\mathrm{H}_{\mathrm{U}}$, [ $\mathrm{W} \mathrm{K}^{-1}$ ].

In general, $\mathrm{H}_{\mathrm{x}}$ consists of three terms [12]:

$\mathrm{H}_{\mathrm{x}}=\mathrm{b}_{\mathrm{tr}, \mathrm{x}}\left[\Sigma_{\mathrm{i}} \mathrm{A}_{\mathrm{i}} \mathrm{U}_{\mathrm{i}}+\Sigma_{\mathrm{k}} \mathrm{l}_{\mathrm{k}} \psi_{\mathrm{k}}+\Sigma_{\mathrm{j}} \chi_{\mathrm{j}}\right] \quad\left[\mathrm{W} \mathrm{K}^{-1}\right]$

where:

- $\mathrm{A}_{\mathrm{i}}$ is the area of the $\mathrm{i}$-element of the building envelope $\left[\mathrm{m}^{2}\right]$

- $\mathrm{U}_{\mathrm{i}}$ is the thermal transmittance of the i-element of the building envelope $\left[\mathrm{W} \mathrm{m}^{-2} \mathrm{~K}^{-1}\right]$;

- $\quad l_{\mathrm{k}}$ is the length of the $\mathrm{k}$-linear thermal bridge $[\mathrm{m}]$;

- $\psi_{\mathrm{k}}$ is the linear thermal transmittance of the $\mathrm{k}$-thermal bridge $\left[\mathrm{W} \mathrm{m}^{-1} \mathrm{~K}^{-1}\right.$;

- $\quad \chi_{\mathrm{j}}$ is the point thermal transmittance of the $\mathrm{j}$-point thermal bridge $\left[\mathrm{W} \mathrm{K}^{-1}\right.$;

- $b_{t r, x}$ is the adjustment factor for the external temperature [-].

The building energy needs are counted for the heating period defined by the method b) of EN ISO 13790:2008, par.7.4.1.1 and represented by the number of days in the range defined by the days in which the dimensionless heat-balance ratio for the heating mode, $\gamma_{\mathrm{H}}$, is equal to $\gamma_{\mathrm{H}, \mathrm{lim}}$ :

$$
\gamma_{\mathrm{H}}=\left(\mathrm{Q}_{\mathrm{int}}+\mathrm{Q}_{\mathrm{sol}}\right) /\left(\mathrm{Q}_{\mathrm{tr}}+\mathrm{Q}_{\mathrm{ve}}\right)
$$

$\gamma_{\mathrm{H}, \lim }=\left(a_{\mathrm{H}}+1\right) / a_{\mathrm{H}}$

where $a_{\mathrm{H}}$ is a dimensionless numerical parameter depending on the time constant of the building.

\subsection{Hygrothermal performance assessment}

Vapour in air can cause unhealthy conditions: high relative humidity values in the air close to external walls may allow mould growth in the building environment. Moisture transfer through building walls is a very complex process. Variations of the moisture content can influence the material properties. The air movement through cracks or within air spaces may change the moisture distribution. Rain or melting snow and the effects of solar radiation may also affect the moisture conditions inside the structures.

A simplified calculation method, described in EN ISO 13788 Standard [13], is assumed for the assessment of the risk of interstitial condensation due to moisture transfer through layers, neglecting other aspects, e.g. ground water, precipitation, built-in moisture, and moisture convection. The Standard indicates also a method to assess the risk of mould growth on wall surfaces, which in this analysis has not be considered.

The method represents the assessment of the annual moisture balance and of the maximum amount of accumulated moisture. It is suitable for comparing building structures and their thermal improvement. The procedure is based on the "Glaser method".

Monthly mean values of external air temperature and relative humidity are needed. From them, the external monthly mean vapour pressure, $P_{e}$ is calculated, while the monthly mean values of $\mathrm{P}_{\mathrm{i}}$, referred to the internal conditions, are chosen according to the expected use of the building.

Moreover, the thermophysical properties of wall layers (thermal conductivity or resistance, vapour permeability) and thicknesses must be considered.

Effects, such as air movements through or within the building elements, are not considered. For each month of the year, the temperature distribution in each layer is calculated in steady state conditions, and from its values, the saturation vapour pressure is determined at each interface between material layers.

The saturation vapour pressure can be compared graphically with the vapour pressure calculated by the Fick's Law that indicates the relation between the vapour flow rate $g$ through the building element and the vapour pressure difference $\Delta \mathrm{P}$ on the internal/external environments:

$g=\delta_{o} \frac{\Delta P}{s_{d}} \quad\left[k^{-2} \mathrm{~s} \mathrm{~m}^{-1}\right]$

where:

$\delta_{0}=2 \times 10^{-10} \mathrm{~kg} \mathrm{~m}{ }^{-1} \cdot \mathrm{s}^{-1} \cdot \mathrm{Pa}^{-1}$ water vapour permeability of air with respect to partial vapour pressure;

$\mathrm{s}_{\mathrm{d}}=\mu \mathrm{s}=$ water vapour diffusion-equivalent air layer thickness [m];

$\mathrm{s}=$ material layer thickness $[\mathrm{m}]$;

$\mu=$ water vapour resistance factor [-].

The vapour pressure profile between the internal and external vapour pressure $\left(\mathrm{P}_{\mathrm{i}}\right.$ and $\left.\mathrm{P}_{\mathrm{e}}\right)$ is a straight line if condensation does not occur. Comparing it with the saturation pressure on a graph with the $s_{d}$ values on the $\mathrm{x}$-axis, if the 
vapour pressure exceeds the saturation pressure at any interface, the condensation occurs.

The vapour pressure is redrawn as a series of lines that do not exceed the saturation pressure profile, and that touch it at as few points as possible. These points correspond to the condensation interfaces.

The method described in [8] allows, through these steps, to determine the amount of condensation and evaporation for each month.

One of the following results will be obtained by the assessment:

- $\quad$ absence of condensation at any interface in any month: the test is passed.

- condensation occurs, but the calculations show that the condensate evaporates during the warmer months. The effects of the maximum amount of moisture shall be considered (degradation of building materials or thermal performance deterioration);

- condensation does not completely evaporate during the warmer months: the structure has failed the assessment.

The Standard in fact indicates as verified a building wall, if the condensation can be completely dried throughout the year, and if it does not exceed the limit values of the materials involved. However, in case of accumulation of condensate over $200 \mathrm{~g} \mathrm{~m}^{-2}$, even if it can be evaporated, the risk of water run-off from non-absorbent materials will be very high. This effect, and also building materials degradation and thermal performance deterioration, consequence of the calculated maximum amount of moisture, should be managed by national regulations.

\section{EVALUATION PROCEDURE - APPLICATION TO A CASE STUDY}

The calculation methodology, previously proposed [8] has been extended: it was developed mainly to achieve the energy saving objectives jointly with the respect of the constraints about vapour condensation inside walls, and now details on the cost analysis have been added. The whole methodology is here outlined.

\subsection{Procedure}

The methodology indicated in [8], completed by means of an economic investigation with the costs evaluation procedure [14], is reported in Fig.1.

The main steps to follow are synthetized here below:

1. Definition of the case study: wall's typologies (materials and layers order), envelope's geometry.

2. Boundary conditions: intended use, indoor climatic conditions, climatic zone.

\section{Evaluation methodologies:}

3a) Energy performance calculations (EN ISO 13790, [11])

3b) Hygrothermal performance assessment of building walls (EN ISO 13788, [13])

4. Existing configuration performance calculations:

4a) thermal transmittance $U$;

4b) vapour condensation risk assessment.

5. Target definition for each aspect considered in the global assessment (NZEB target or national limits corresponding to refurbishment, etc., absent or limited interstitial condensation risk).
6. Retrofit: insulating material choice (external, internal, air layer insulation) and its thickness. Energy performance and vapour condensation risk assessment for a maximum number $i_{\max }$ of attempts to fulfil the NZEB requirements

7. Refurbishment: insulating material choice (external, internal, air layer insulation) and its thickness. Energy performance and vapour condensation risk assessment for a maximum number $k_{\max }$ of attempts to fulfil the refurbishment requirements. The combination material/thickness considered in step 6 are likely to be the starting point for this step.

8. Output: the building could be already a NZEB or could be retrofitted as a NZEB, refurbished to a good energy performance level, or it needs a complete rebuilding.

9. Cost optimal assessment: according to the EPDB [1], "cost-optimal level" means the energy performance level which leads to the lowest cost during the estimated economic lifecycle. To estimate the cost-optimal level, meanwhile obtaining the energy results for the retrofit solutions, the Global Cost of the intervention is calculated, according to EN 15459:2007 [15]:

$$
\mathrm{C}_{\mathrm{G}}(\tau)=\mathrm{C}_{\mathrm{I}}+\sum_{\mathrm{j}}\left[\sum_{\mathrm{i}=1}^{\tau}\left(\mathrm{C}_{\mathrm{a}, \mathrm{i}}(\mathrm{j}) \times \mathrm{R}_{\mathrm{d}}(\mathrm{i})\right)-\mathrm{V}_{\mathrm{f}, \tau}(\mathrm{j})\right]
$$

where:

- $\quad \mathrm{C}_{\mathrm{I}}$, Initial Investment Costs;

- Ca,i(j), the Annual Costs for the component $\mathrm{j}$ at the year $i$, determined considering a calculation period of 30 years in accordance to the Guidelines [2] for retrofit analysis. The Annual Costs involve both energy consumption and operational, maintenance and replacement costs. To obtain the energy costs, gas and electricity consumptions provided by the quasi-state simulation should be multiplied with the tariffs set by the local Regulatory Authority for Electricity Gas and Water. To consider the variation of the energy prices, an actualization factor should be applied. Maintenance and replacement costs of systems components are provided by the Annex A of the Standard EN 15459 [15];

Rd(i), the discount Rate at the year i calculated by using the Market Rate and the Inflation Rate;

Vf,t $(j)$, the Final Value of the component $j$, evaluated in function of the lifespan at the end of the calculation period and then subtracted at the last replacement cost.

Throughout the correlation between global costs for square floor meter and primary energy use, the cost-optimal graph is defined, where the lowest points define the cost-optimal solutions' range.

Following the procedure, the cases that pass through the cost optimal assessment have been already verified for the energy performance levels and the condensation risk. Therefore, the cost optimal solutions are definitively the best ones for all the considered aspects. A further step should be defined depending on national indications, to find the most suitable financial tools for the selected intervention.

\subsection{The case study of a social housing apartment}

A widely diffuse class of buildings, which are particularly high demanding in terms of energy needs, is represented by social housing buildings. They are not subjected to particular constraints due to architectural and historical value 
preservation, which allows different interventions on the building envelope to reduce the energy consumption.

As a representative case study, a small apartment, set in an intermediate floor of a tall building is analysed (Fig.2). The apartment is an open-space, having net floor sides $\mathrm{L}=10 \mathrm{~m}$, $\mathrm{D}=5 \mathrm{~m}$ and an internal height $\mathrm{h}=2.70 \mathrm{~m}$. Moreover, it has only one external wall, facing North (to minimize the solar gain influence), with two windows $\left(\mathrm{L}_{\mathrm{w}}=1.2 \mathrm{~m}, \mathrm{~h}_{\mathrm{w}}=1.4 \mathrm{~m}\right)$ and one French window $\left(\mathrm{L}_{\mathrm{w}}=1.2 \mathrm{~m}, \mathrm{~h}_{\mathrm{w}}=2.2 \mathrm{~m}\right)$. All the other walls are internal and face heated spaces, which means they are not interested by heat transfer.
The considered initial conditions of the transparent envelope are quite common for this kind of apartment built in the 60'-70' period: all the windows are single-glazed, with a thermal transmittance $\mathrm{U}_{\mathrm{g}}=5.7 \mathrm{~W} \mathrm{~m}^{-2} \mathrm{~K}^{-1}$ for the glass and $\mathrm{U}_{\mathrm{f}}$ $=2.8 \mathrm{~W} \mathrm{~m}^{-2} \mathrm{~K}^{-1}$ for the frame (made of metal, with thermal cut). The frame percentage is about $25.3 \%$ for the French window and $28.3 \%$ for the windows. The resulting weighted values are $\mathrm{U}_{\mathrm{w}}=4.965 \mathrm{~W} \mathrm{~m}^{-2} \mathrm{~K}^{-1}$ for the French window and $\mathrm{U}_{\mathrm{w}}=4.880$ $\mathrm{W} \mathrm{m} \mathrm{m}^{-2} \mathrm{~K}^{-1}$ for the windows.

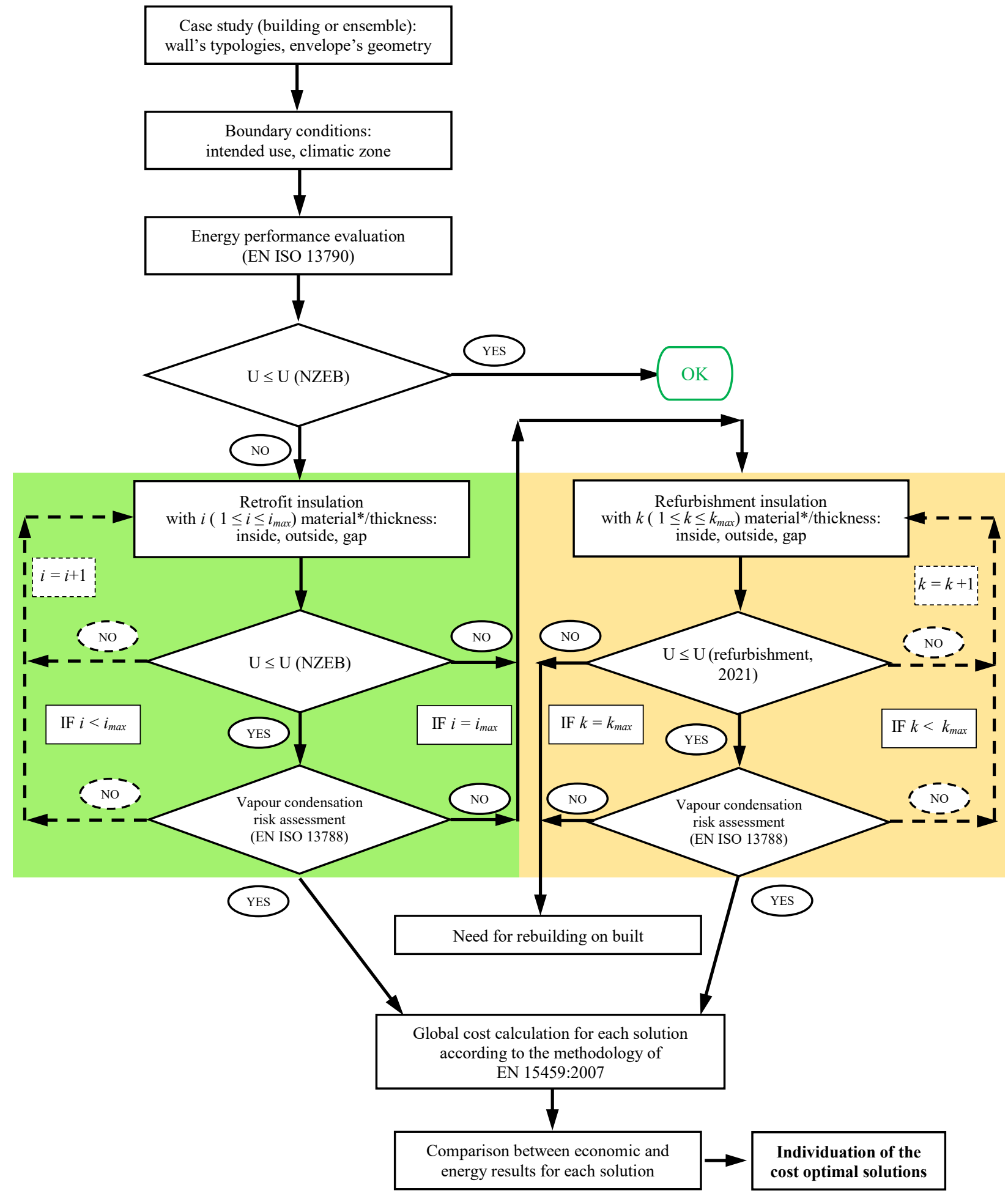

Figure 1. Procedure flow-chart 
Two external wall typologies, representative of some social housing buildings [16], with and without air layer, are considered and their thermophysical properties are reported in Table 1. Each one is taken into account in the calculations as the envelope of each single case representing the existing configuration.

In order to best focusing on the behaviour of the external wall due to its layer composition, thermal bridges are here neglected, since they account mainly for the interaction among different structures.

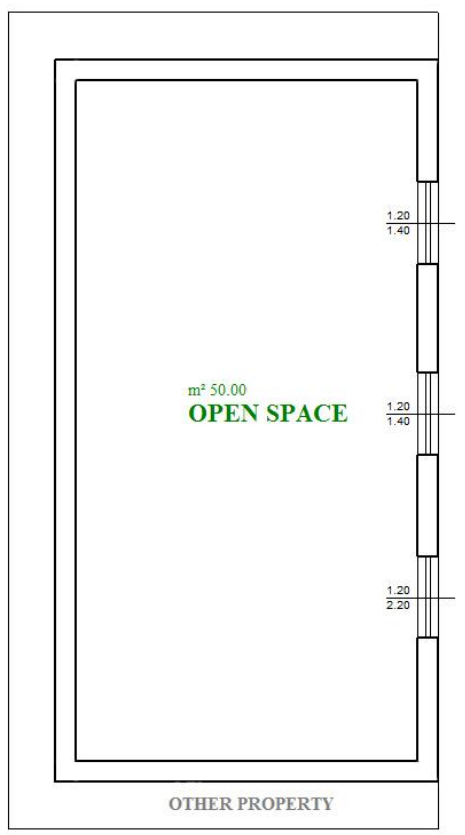

Figure 2. Sketch of the apartment considered, having one external wall, facing North, with two windows and one French window.

Table 1. Building walls characteristics

\begin{tabular}{|c|c|c|c|c|}
\hline \\
\hline \multicolumn{5}{|c|}{$\begin{array}{cl}\text { W1 - Air layer brick masonry } \\
\text { Layer } & \mathrm{S} \\
{[\mathrm{cm}]}\end{array}$} \\
\hline & $\begin{array}{l}1 \text { Internal } \\
\text { plaster }\end{array}$ & 2 & 0.700 & - \\
\hline & $\begin{array}{l}2 \text { Hollow } \\
\text { bricks }\end{array}$ & 12 & - & 0.310 \\
\hline & 3 Air layer & 10 & - & $0.180^{\text {a) }}$ \\
\hline & 4 Bricks & 12 & 0.720 & - \\
\hline & Thermal & & $1.169 \mathrm{~W} \mathrm{~m}$ & $\mathrm{~K}^{-1}$ \\
\hline & a) EN ISO & & & \\
\hline
\end{tabular}

\begin{tabular}{|c|c|c|c|c|}
\hline \multicolumn{5}{|c|}{ W2 - Concrete wall } \\
\hline & Layer & $\begin{array}{l}\mathrm{s} \\
{[\mathrm{cm}]}\end{array}$ & $\begin{array}{l}\lambda \\
{\left[\mathrm{W} \mathrm{m} \mathrm{m}^{-1} \mathrm{~K}^{-1}\right]}\end{array}$ & $\begin{array}{l}\mathrm{R} \\
{\left[\mathrm{m}^{2} \mathrm{KW}^{-1}\right]}\end{array}$ \\
\hline & $\begin{array}{l}1 \text { Internal } \\
\text { plaster }\end{array}$ & 1 & 0.700 & - \\
\hline & $\begin{array}{l}2 \text { Concrete } \\
\text { panel }\end{array}$ & 25 & 0.580 & - \\
\hline & \multicolumn{2}{|l|}{ Thermal } & \multicolumn{2}{|c|}{$1.626 \mathrm{~W} \mathrm{~m}^{-2} \mathrm{~K}^{-1}$} \\
\hline
\end{tabular}

Both W1 and W2 walls are retrofitted by considering an internal insulation having an overall thickness of $7 \mathrm{~cm}(5 \mathrm{~cm}$ of insulating layer and $2 \mathrm{~cm}$ of internal plaster), which represents a meanly acceptable reduction of the internal space. Moreover, wall W1, which presents an internal air layer with a thickness equal to $10 \mathrm{~cm}$ (a common value for social housing buildings), can be insulated also by filling this space by means of a loose insulating material (cellulose or polyurethane foam). External insulation was disregarded, as often that action must be evaluated if the whole façade restoration is needed, due to the high costs of the scaffolding.

Table 2 reports the main properties of the insulating materials that have been chosen for the energy retrofit of the existing walls among those that are commonly used and easily available on the market. Two typologies of materials respectively for internal and air layer insulation have been chosen, considering their thermal conductivity and sustainability level. The choice of the insulating materials has been made also accounting for their sustainability in terms of environmental degradation, climate change, and energy consumption.

With reference to the retrofit of the transparent part of the envelope, the substitution of all the windows with more performant others is considered. In detail, a double glass 4-8$4 \mathrm{~mm}$, filled with Argon, with a low emissivity surface treatment and a PVC frame with three empty rooms is adopted in all the retrofitting solutions.

Table 2. Thermo-physical parameters of the insulating materials

\begin{tabular}{cccc}
\hline Insulating materials & $\begin{array}{c}\lambda \\
{\left[\mathrm{W} \mathrm{m}^{-1} \mathrm{~K}^{-1}\right]}\end{array}$ & $\begin{array}{c}\rho \\
{\left[\mathrm{kg} \mathrm{m}^{-3}\right]}\end{array}$ & $\begin{array}{c}\delta \\
{\left[\mathrm{kg} \mathrm{m}^{-1} \mathrm{~s}^{-1} \mathrm{~Pa}^{-1}\right]}\end{array}$ \\
\hline \multicolumn{2}{c}{ Internal insulation } \\
\hline Wooden fibre board & 0.040 & 110 & $97.010^{-12}$ \\
\hline Polystyrene & 0.033 & 35 & $1.310^{-12}$ \\
\hline Air layer insulation & & & \\
\hline Cellulose & 0.055 & 35 & $20010^{-12}$ \\
\hline Polyurethane foam & 0.030 & 30 & $3.810^{-12}$
\end{tabular}

\subsection{Calculations and analyses of the results}

\subsubsection{Example of the procedure application}

A first set of input data was chosen to apply the complete methodology (energy performance, condensation risk, and cost-optimal solutions analyses) to the case study.

On the basis of the flow chart of Fig. 1, the following steps were developed:

1. Case study definition, as described in Par.3.2

2. Boundary conditions, for Italy, according to [17], and:

- $\quad$ climatic data referred to Milan (Italy);

- apartment occupancy: medium level (for the condensation risk assessment)

- internal temperature set to $20^{\circ} \mathrm{C}$ in the heating period (both for energy and for condensation calculations)

3. Energy performance evaluation (existing building).

Comparison of the U-values (wall and windows) with the maximum values for the refurbishment and NZEB indicated by the Italian national legislation, reported in Table 3 (Ref. Table 1, Appendix B, [18]), referring to the climatic zone of Milan. 
Table 3. External building walls: comparison between existing building and maximum allowed $\mathrm{U}$-values

\begin{tabular}{cccc}
\hline $\begin{array}{c}\text { U-values } \\
{\left[\mathrm{W} \mathrm{m}^{-2} \mathrm{~K}^{-1}\right]}\end{array}$ & $\begin{array}{c}\text { existing } \\
\text { building }\end{array}$ & $\begin{array}{c}\text { refurbishment } \\
(2021)\end{array}$ & NZEB \\
\cline { 1 - 2 } Wall W1 & 1.169 & 0.28 & 0.26 \\
\cline { 1 - 2 } Wall W2 & 1.626 & & 1.4 \\
\hline Windows & $4.965-4.880$ & 1.4 & 1.4 \\
\hline
\end{tabular}

The comparison shows clearly the difference between the U-values considered in the case study and the limits imposed by the national legislation.

4. Retrofit insulation. The chosen insulating materials are the ones indicated in Table 2. Only one package configuration for the internal insulation has been chosen: insulating layer, $5 \mathrm{~cm}$, internal plaster, $2 \mathrm{~cm}$, applied on the entire existing wall. The air gap of the $\mathrm{W} 1$ wall is considered filled by insulating materials for the entire thickness. The case of air gap insulation combined with internal insulation is also calculated. Table 4 shows when the analysed cases fit the NZEB Italian reference U-value.

Table 4. U-values of the existing walls and the proposed retrofit insulation measures

\begin{tabular}{|c|c|c|c|c|}
\hline $\mathbf{N}$ & $\begin{array}{l}\text { Wall and retrofit } \\
\text { insulation }\end{array}$ & $\begin{array}{c}\text { U-values } \\
{\left[\mathbf{W} \mathbf{m}^{-2} \mathbf{K}^{-1}\right]}\end{array}$ & $\begin{array}{c}\text { NZEB } \\
\mathbf{U}=\mathbf{0 . 2 6} \\
\mathbf{W} \mathbf{~ m}^{-2} \mathbf{K}^{-1}\end{array}$ & $\begin{array}{c}\text { free from } \\
\text { condensation }\end{array}$ \\
\hline 1 & W1 - Existing wall & 1.169 & $\mathrm{NO}$ & YES \\
\hline 2 & $\mathrm{~W} 1$ + Cellulose & 0.402 & NO & NO \\
\hline 3 & $\begin{array}{l}\mathrm{W} 1+\text { Polyurethane } \\
\text { foam }\end{array}$ & 0.249 & YES & YES \\
\hline 4 & W1 + Wooden fibre & 0.469 & $\mathrm{NO}$ & $\mathrm{NO}^{\mathrm{c}}$ \\
\hline 5 & W1 + Polystyrene & 0.417 & $\mathrm{NO}$ & YES \\
\hline 6 & $\begin{array}{c}\mathrm{W} 1+ \\
\text { Cellulose+wooden fibre }\end{array}$ & 0.265 & $\mathrm{NO}^{\mathrm{a}}$ & $\mathrm{NO}^{\mathrm{c}}$ \\
\hline 7 & $\begin{array}{c}\text { W1 + } \\
\text { Cellulose+polystyrene }\end{array}$ & 0.248 & YES & YES \\
\hline 8 & $\begin{array}{l}\text { W1 + Polyurethane } \\
\text { foam+wooden fibre }\end{array}$ & 0.189 & YES & YES \\
\hline 9 & $\begin{array}{l}\mathrm{W} 1 \text { + Polyurethane } \\
\text { foam+polystyrene }\end{array}$ & 0.180 & YES & YES \\
\hline 10 & W2 - Existing wall & 1.626 & NO & YES \\
\hline 11 & $\mathrm{~W} 2+$ Wooden fibre & 0.528 & NO & $\mathrm{NO}^{\mathrm{b}, \mathrm{c}}$ \\
\hline 12 & W2 + Polystyrene & 0.463 & NO & YES \\
\hline
\end{tabular}

${ }^{a}$ the U-Value fits the limit for refurbishmen

${ }^{\mathrm{b}}$ the condensation amount is higher than $200 \mathrm{~g} \mathrm{~m}^{-2}$

${ }^{\mathrm{c}}$ free from condensation if a Vapour Barrier (VB) is applied

5. Vapour condensation risk assessment. In the last column of Table 4 , the condensation assessment of the four walls that have passed the previous check shows that they are all free from condensation.

The amount of condensed water takes place in winter (December-January). The calculations carried out for the whole year show that it evaporates completely in the summer period. For wall n.11 however the amount of condensation overcomes the recommended limit [13]. In any case, these walls do not pass the check, considering the Italian national Decree [18] for which the walls must be completely free from the condensation risk.

The four walls with $\mathrm{U}<\mathrm{U}_{\text {NZEB }}$ and free from condensation (n.3-7-8-9, Tab. 4) are ready for the global cost calculations.
6. Refurbishment insulation. The other walls, following the procedure, pass through the check related to the refurbishment insulation: the reference $U$-value here is related to the refurbishment actions (Tab.1). Only solution n.6 passes the check related to the U-value.

The condensation risk assessment for wall n.6 is not positive: it is affected by condensation. Therefore, it returns to step 6: the solution can be represented by a thin layer of a vapour barrier VB under the internal plaster layer. In these conditions, the heat transmittance does not change significantly, but the condensation risk becomes zero. Also, wall n.6 can be processed to obtain the cost optimal solution. To support a wider analysis of the results, also the calculations for the other walls were performed, even if not necessary.

7. Cost assessment. Finally, three insulation proposals allow to reach NZEB local requirements, and one is suitable only for respecting the refurbishment limits. All of them can be processed to verify the cost optimal solutions by means of Eq.8, with the following assumptions:

$\mathrm{C}_{\mathrm{I}}$, Initial Investment Costs, achieved from the price list for the execution of public works and maintenances of the City of Milan [19].

$\mathrm{Ca}, \mathrm{i}(\mathrm{j})$, to obtain the Energy Costs, gas and electricity consumptions provided by the quasi-state simulation were multiplied with the tariff set by the Italian Regulatory Authority for Electricity Gas and Water (€ $0.16 \mathrm{kWh}-1$ for electricity, $€ 0.75 \mathrm{~m}-3$ for natural gas) [20]. The variation of the energy prices is taken into account with an actualization factor of $2 \%$ [21]. When data about maintenance and replacement costs of systems components were not available, market analyses were performed.

Rd(i), the discount Rate at the year $i$ is calculated by using a Market Rate of 4\% [21] and an Inflation Rate of 0,49\% [22], calculated comparing the December 2016 CPI to the December 2015 CPI.

8. Individuation of the cost optimal solutions. In Fig. 3 the results of the whole analyses are represented.

The U-value, the $\mathrm{Q}_{\mathrm{H}, \mathrm{nd}}$, the $\mathrm{EP}_{\mathrm{H}}$ (primary energy) and the heating period of each improvement solution are represented as a percentage of the corresponding value referred to the existing wall (scale on the left axis); the corresponding Global Cost $\mathrm{C}_{\mathrm{G}}$ is indicated on the right axis.

On the left side, the four cases that passed all the requirements indicated in the procedure are compared, to highlight the cost optimal solutions. The fifth case is useful only if the procedure is adopted to compare the solutions on the basis of the refurbishment target. On the right side, the results are referred to the insulating actions that do not satisfy the requirements: they can be useful for a general comparison. The cost optimal solution is indicated with the blue arrow, n.9, considering the Global Cost $\mathrm{C}_{\mathrm{G}}$ and the primary energy $\mathrm{EP}_{\mathrm{H}}$. It is the best one also referring to the $\mathrm{U}$-value and the annual energy needs for the building envelope $\mathrm{Q}_{\mathrm{H}, \mathrm{nd}}$. The yellow arrows with VB indicate the Vapour Barrier need, the red arrow indicates the rejected solutions due to condensation problems. The other cases are not affected by condensation.

Some observations can be highlighted on the results of the application of the procedure:

- $\quad$ in this example, starting from ten different insulating actions (Tab.4), the procedure allows to reduce progressively the calculations excluding the ones that do not fit the targets;

- $\quad$ solutions n.2 and n.3 are the cheapest ones, however they have a U-value too high and for the $n .2$ wall the air gap 
filling with cellulose cannot be modified to avoid the condensation risk;

- $\quad$ excluding n.2 and n.3, the cheapest solutions are contemporarily the best ones from the economic point of view and from the primary energy reduction. Three of them reach the NZEB target, the fourth (n.6) reaches the refurbishment target but is evaluable only if a VB can be applied;

- $\quad$ if the use of VB is not suitable for the application, some wall improvement solutions cannot be compared.

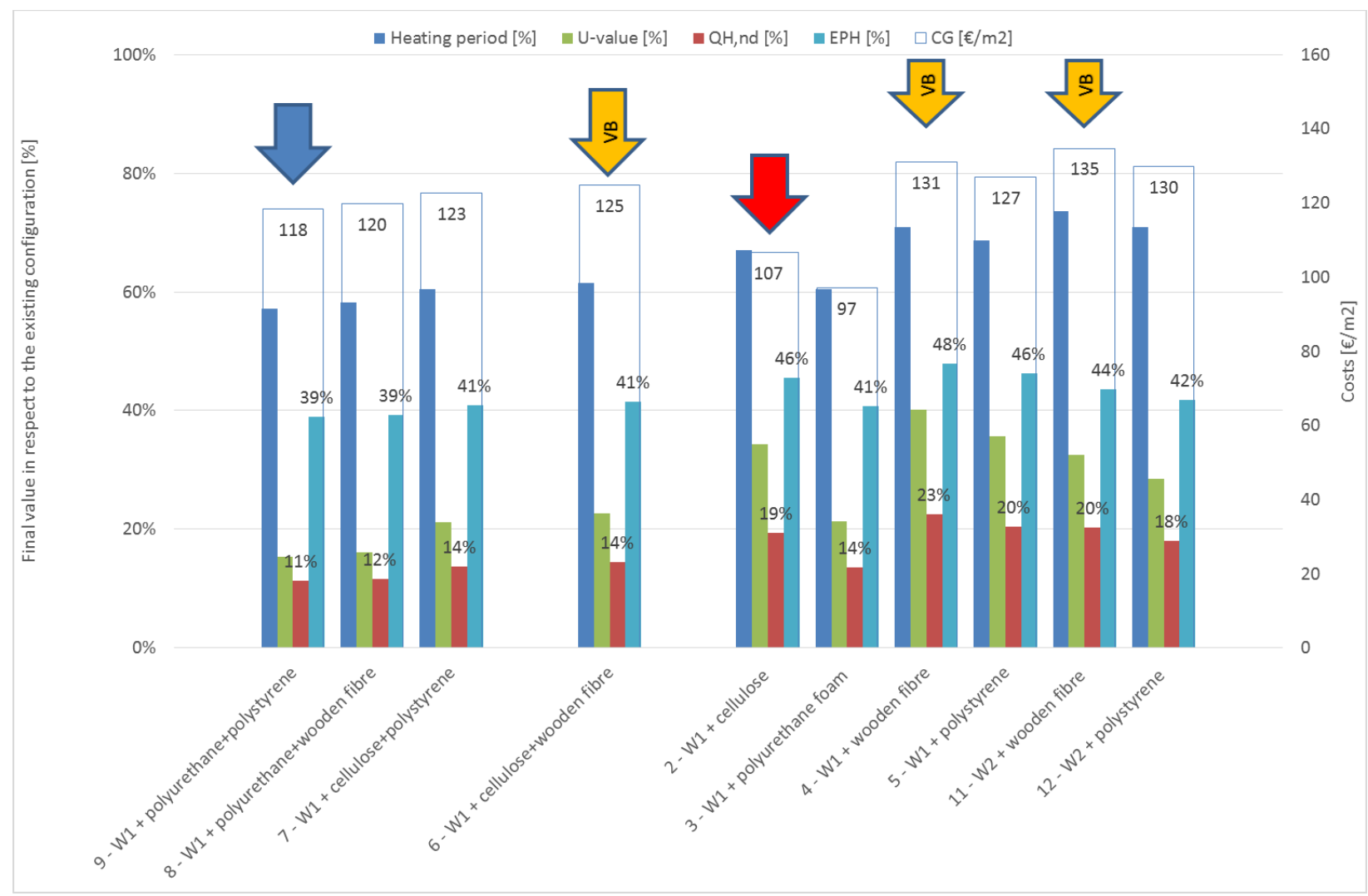

Figure 3. Results of the procedure application - Climatic conditions of Milan

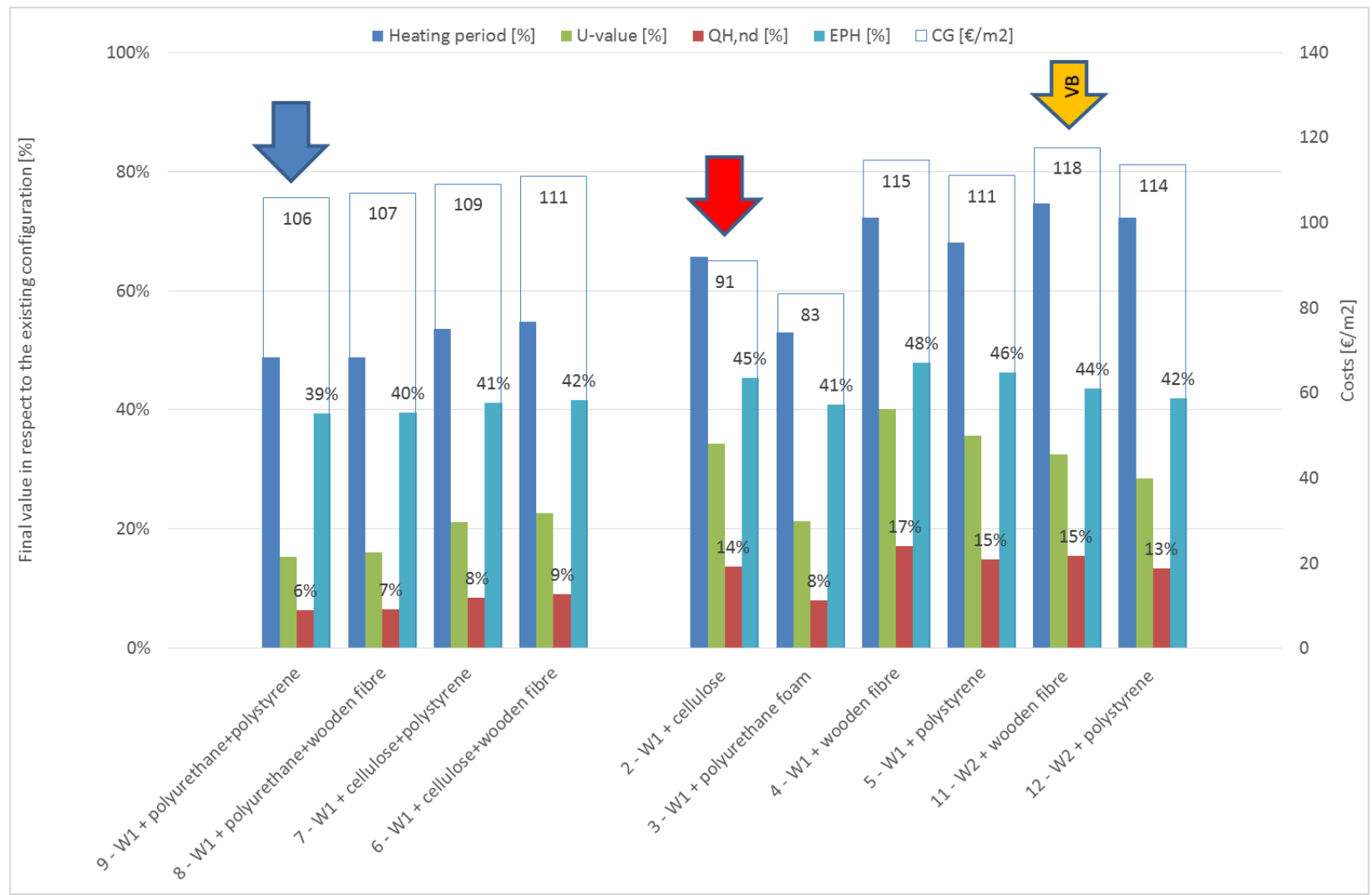

Figure 4. Results of the procedure application - Climatic conditions of Livorno 
3.3.2 Comparison between different locations in the same country

The procedure has been applied to another location, in order to analyse the influence of climatic conditions on the best solution choice. In order to evaluate the impact of the retrofit for different climatic zones in the same Country, the climatic conditions, typical of the continental and coastal Italian territory respectively, are compared: Milan (climatic zone E) and Livorno (climatic zone D). The limits in these two zones, in respect of the National Laws, are synthetized in Table 5.

The same conditions as in the previous calculations were considered namely:

- apartment occupancy: medium level (for the condensation risk assessment)

- internal temperature set to $20^{\circ} \mathrm{C}$ in the heating period (both for energy and for condensation calculations)

Table 5. External building walls: comparison between existing building and maximum allowed $\mathrm{U}$-values

\begin{tabular}{cccc}
\hline Climatic zone & \multicolumn{3}{c}{ U-values [W $\mathbf{~ m}^{-2} \mathbf{K}^{-\mathbf{1}}$ ] } \\
\hline & Refurbishment (2021) & NZEB & Windows \\
\hline zone D & 0.32 & 0.29 & 1.8 \\
zone E & 0.28 & 0.26 & 1.4 \\
\hline
\end{tabular}

The results for Livorno are represented in Fig.4. From the comparison, it can be observed that four improvement solutions fit the NZEB limits: they are free from condensation, and can be processed for the cost optimal solution that gives the same indications as for the Milan climatic conditions.

Generally, the condensation risk assessment shows better results than for the Milan climatic conditions, because only two cases are affected by condensation; one of them can be improved by means of the application of a Vapour Barrier.

The global costs for Livorno are lower than for Milan as the running costs of the two locations are different, while the initial investment costs remain the same, due to the same considered retrofit solutions.

3.3.3 Comparison between different locations in two countries

A third analysis was performed to highlight the importance of the combined effects of temperature and humidity on the results both for energy performance and for condensation risk, without taking into account the economic analysis, due to the differences of costs, depending on the Countries.

Table 6. Geographical data and heating degree-days of the four cities

\begin{tabular}{|c|c|c|c|}
\hline Location & GPS Coordinates & $\begin{array}{c}\text { Altitude } \\
\text { above sea } \\
\text { level [m] }\end{array}$ & $\begin{array}{c}\text { Degree days } \\
{\left[{ }^{\circ} \mathrm{C} \text { day }\right]}\end{array}$ \\
\hline Milan (IT) & $\begin{array}{l}\text { Lat. } 45^{\circ} 27^{\prime} 51^{\prime} ’ \mathrm{~N} \\
\text { Long. } 9^{\circ} 11^{\prime} 25^{\prime}, \mathrm{E}\end{array}$ & 122 & 2404 \\
\hline Livorno (IT) & $\begin{array}{l}\text { Lat. } 43^{\circ} 32^{\prime} 36^{\prime \prime} 96 \mathrm{~N} \\
\text { Long. } 10^{\circ} 19^{\prime} 1 " 20 \mathrm{E}\end{array}$ & 3 & 1408 \\
\hline Lyon (FR) & 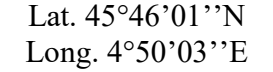 & 173 & 2656 \\
\hline $\begin{array}{l}\text { Marseille } \\
\text { (FR) }\end{array}$ & $\begin{array}{l}\text { Lat. } 43^{\circ} 17^{\prime} 51^{\prime \prime} \mathrm{N} \\
\text { Long. } 5^{\circ} 22^{\prime} 38^{\prime} ' \mathrm{E}\end{array}$ & 12 & 1760 \\
\hline
\end{tabular}

In this case the comparison has considered the previous cases (Milan and Livorno) and the climatic conditions of two cities in France, i.e., Lyon and Marseille, with similar location, respectively in the middle of the country and facing the Mediterranean Sea (Tab.6). The comparison between the climatic data of the colder months is represented in Fig. 5 and Fig.6, comparing Livorno with Marseille (both facing the Mediterranean Sea) and Milan with Lyon (both characterised by a continental climate).

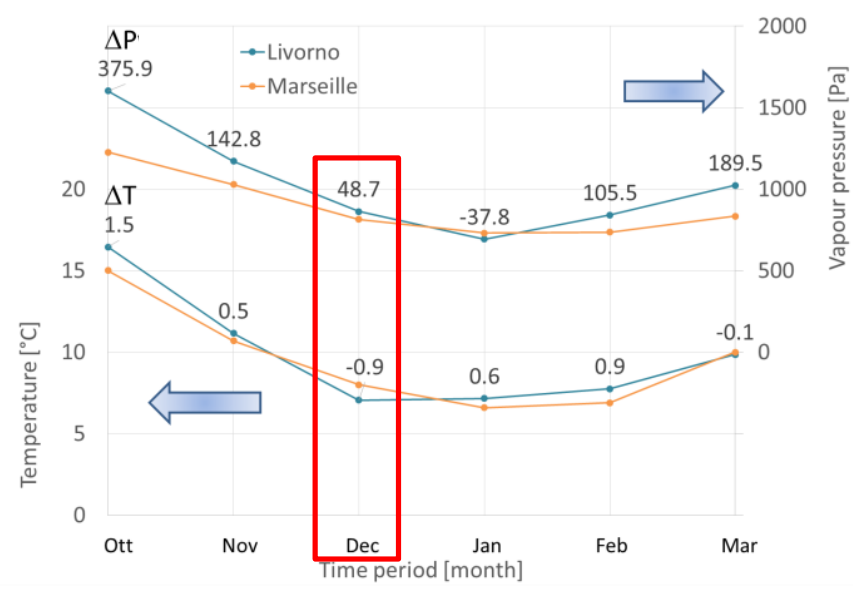

Figure 5. External temperature and vapour pressure of Livorno and Marseille in the heating period

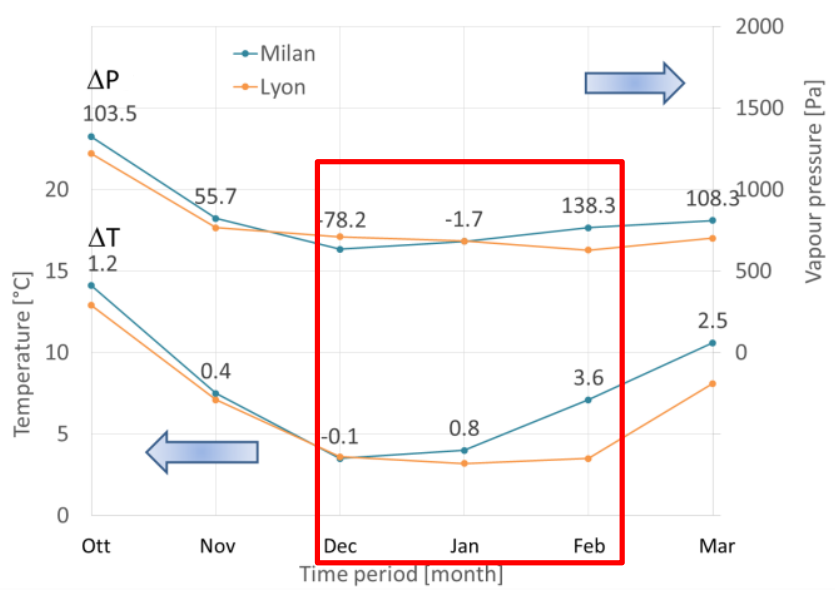

Figure 6. External temperature and vapour pressure of Milan and Lyon

Table 7. Reference case and walls affected by condensation

\begin{tabular}{|c|c|c|c|c|c|}
\hline \multirow[t]{2}{*}{$\mathbf{N}$} & \multirow[t]{2}{*}{$\begin{array}{c}\text { Walls and retrofit } \\
\text { insulation }\end{array}$} & \multirow[t]{2}{*}{$\begin{array}{c}\text { U-values } \\
{\left[\mathbf{W} \mathbf{~ m}^{-2} \mathbf{K}^{-1}\right]} \\
\end{array}$} & \multicolumn{3}{|c|}{$\begin{array}{c}\text { Condensation risk } \\
\text { assessment }\end{array}$} \\
\hline & & & LI MA & MI & LY \\
\hline 1 & W1 - Existing wall & 1.169 & & & \\
\hline 2 & $\mathrm{~W} 1$ + Cellulose & 0.402 & $<200$ & $<200$ & $>200$ \\
\hline 4 & W1 + Wooden fibre & 0.469 & & $<200$ & $>200$ \\
\hline 6 & $\begin{array}{l}\mathrm{W} 1+\text { Cellulose+wooden } \\
\text { fibre }\end{array}$ & 0.265 & & $<200$ & $>200$ \\
\hline $\begin{array}{l}1 \\
0\end{array}$ & W2 - Existing wall & 1.626 & & & \\
\hline $\begin{array}{l}1 \\
1\end{array}$ & W2 + Wooden fibre & 0.528 & $<200$ & $>200$ & $>200$ \\
\hline
\end{tabular}

The climatic conditions are similar: in Fig.5 and 6, over the lines representing $\mathrm{T}$ (temperature) and $\mathrm{P}$ (vapour pressure), the 
difference between two corresponding climatic conditions is indicated respectively as $\Delta \mathrm{T}$ and $\Delta \mathrm{P}$. The values show small differences. The climatic conditions of Livorno, in December, with slightly lower temperature and higher vapour pressure than Marseille, produce the condensed water, as indicated in Table 7 for the $n .2$ and $n .11$ walls.

Referring to the wall list in Table 4 , in Table 7 the condensation risk is compared, indicating only the walls with condensation and when it is higher than the suggested limit of $200 \mathrm{~g} \mathrm{~m}^{-2}$ (even if it results evaporating in the annual cycle) [13]. The same conditions as in the previous calculations were considered (occupancy and internal temperature).

Generally, lower values of external temperature define a saturation pressure profile inside the wall that, associated to higher values of external vapour pressure, can produce suitable conditions for the condensation risk inside the wall, depending on its layers composition.

The comparison between the climatic conditions of Milan and Lyon show a slight difference in December and January, when condensation occurs in both locations, while in February the higher temperature and vapour pressure in Milan than in Lyon produce condensation only in the second location. Anyway, the condensation is higher in Lyon than in Milan and overcomes the indicated limit in all the cases. Only wall n.11 is critical from this point of view also in Milan.

Except for n.2 wall, all the structures could be free by condensation if a VB is added.

\section{CONCLUSIONS}

In this work, a procedure for the energy renovation design of building walls previously proposed has been completed with the economic evaluation of the considered solutions.

The combined analysis of refurbishment actions has been applied to a case study of a little apartment taking into account the energy performance and the condensation risk assessment. The calculations were finalized to apply the procedure to the apartment using the climatic conditions of different towns, and to demonstrate its capabilities, highlighting the need for simultaneous assessment of thermal and moisture problems and costs evaluation. The condensation risk assessment gives results that are not only related to the external temperatures but also to the external vapour pressure, and therefore they are not immediately evident, if not calculated properly.

The results should lead to a smart selection of materials and their correct application, according to the climatic conditions. The potentialities of an integrated procedure can be used also for an appropriate material selection in terms of sustainability. The case study has taken into account also this aspect, even if marginally, by the use of more or less sustainable insulating materials. Anyhow, the results can be finalised also to find the best solution that fits requirements in this field.

\section{REFERENCES}

[1] Directive 2010/31/EU of the European Parliament and of Council of 19 May 2010 on the energy performance of building (recast), Official Journal of the European Union, 18.02.2010.

[2] 2012/C 115/01, Guidelines accompanying Commission Delegated Regulation (EU) No 244/2012 of 16 January 2012 supplementing Directive 2010/31/EU of the
European Parliament and of the Council on the energy performance of buildings by establishing a comparative methodology framework for calculating cost-optimal levels of minimum energy performance requirements for buildings and building elements, Official Journal of the European Union, ISSN 1977-091X, Vol. 55, Apr. 2012.

[3] Magrini A., Magnani L., Pernetti R. (2012). The effort to bring existing buildings towards the A class: A discussion on the application of calculation methodologies, Applied Energy, Vol. 97, pp. 438-450, DOI: $10.1016 /$ j.apenergy.2012.01.012

[4] Ferrante A. (2014). Energy retrofit to nearly zero and socio-oriented urban environments in the Mediterranean climate, Sustainable Cities and Society, Vol. 13. pp. 237-253. DOI: 10.1016/j.scs.2014.02.001

[5] Serghides D.K., Dimitriou S., Katafygiotou M.C., Michaelidou M. (2015). Energy efficient refurbishment towards nearly zero energy houses, for the Mediterranean Region, Energy Procedia, Vol. 83, pp. 533-543. DOI: 10.1016/j.egypro.2015.12.173

[6] Kaklauskas A., Zavadskas E.K., Raslanas S. (2005). Multivariant design and multiple criteria analysis of building refurbishments, Energy and Buildings, Vol. 37, pp. 361-372. DOI: 10.1016/j.enbuild.2004.07.005

[7] Baglivo C., Congedo P.M. (2016). High performance precast external walls for cold climate by a multicriteria methodology, Energy, Vol. 115, Part 1, pp. 561576. DOI: $10.1016 /$ j.energy.2016.09.018

[8] Magrini A., Lazzari S., Marenco L. (2017). Energy retrofitting of buildings and hygrothermal performance of building components: Application of the assessment methodology to a case study of social housing, Int. J. of Heat and Technology, Vol. 35, Special Issue 1, pp. 205213. DOI: $10.18280 / \mathrm{ijht} .35 \mathrm{Sp} 0129$

[9] M/480 Mandate to CEN, CENELEC and ETSI for the elaboration and adoption of standards for a methodology calculating the integrated energy performance of buildings and promoting the energy efficiency of buildings, in accordance with the terms set in the recast of the Directive on the energy performance of buildings (2010/31/EU), http://ec.europa.eu/growth/toolsdatabases/mandates/index.cfm?fuseaction=search.detai $1 \& \mathrm{id}=465$.

[10] Magrini A., et al. Building Refurbishment for Energy Performance - A Global Approach, Ed. Springer International, ISBN 978-3-319-03073-9.

[11] CEN: Energy performance of buildings. Calculation of energy use for space heating and cooling, EN ISO 13790 European Committee for Standardization.

[12] CEN: Thermal performance of buildings. Transmission and ventilation heat transfer coefficients - Calculation method, EN ISO 13789, European Committee for Standardization.

[13] CEN: Hygrothermal performance of building components and building elements - Internal surface temperature to avoid critical surface humidity and interstitial condensation - Calculation methods, EN ISO 13788: 2013, European Committee for Standardization.

[14] Guazzi G., Bellazzi A., Meroni I., Magrini A. (2017). Refurbishment design through cost-optimal methodology: The case study of a social housing in the 
northern Italy, Int. J. of Heat and Technology, Vol. 35, Special Issue 1, pp. 336-344. DOI: 10.18280/ijht.35Sp0146

[15] European Standard EN-15459:2007. (2007). Energy performance of buildings-economic evaluation procedure for energy systems in buildings.

[16] Franco G., L'involucro edilizio. Guida alla progettazione e alla manutenzione delle chiusure verticali portate e portanti, (Building envelope. Guide to the design and maintenance of the external walls of buildings), EPC Libri, Roma, 2003, 240 pagg, ISBN 88-8184-303-X.

[17] Italian National Decree D.P.R. 412/1993, Regolamento recante norme per la progettazione, l'installazione, l'esercizio e la manutenzione degli impianti termici degli edifici ai fini del contenimento dei consumi di energia, in attuazione dell'art.4, comma 4, della legge 09.01.1991, n.10 (Regulations for the design, installation, operation and maintenance of heating systems in buildings in order to limit energy consumption, implementing article 4 , paragraph 4 , of Law 09.01.1991, n. 10).

[18] Interministerial Decree, June 26, 2015 - Application of the energy performance calculation methodologies and definition of dispositions and minimum requirements for buildings.

[19] Listino prezzi per l'esecuzione di opera pubbliche e manutenzioni del Comune di Milano, edizione 2017, volume 1.1 Opere compiute civili ed urbanizzazioni e 1.2 Opere compiute impianti elettrici e meccanici (Price list for the execution of public works and maintenances of the City of Milan).

[20] AEEG, Autorità per l'Energia Elettrica, il gas e il sistema idrico (Italian Regulatory Authority for Electricity Gas and Water), www.autorita.energia.it

[21] http://ec.europa.eu/smartregulation/guidelines/tool_54_en.htm

[22] http://www.inflation.eu/inflation-rates/italy/historicinflation/cpi-inflation-italy.aspx

\section{NOMENCLATURE}

$\mathrm{A}_{\mathrm{f}} \quad$ internal floor area of the conditioned space, $\mathrm{m}^{2}$

$a_{\mathrm{H}} \quad$ dimensionless numerical parameter depending on the time constant of the building

$\mathrm{A}_{\mathrm{i}} \quad$ area of the i-element of the building envelope, $\mathrm{m}^{2}$

$b_{t r} \quad$ adjustment factor for the external temperature

D depth, $m$

$\mathrm{C}_{\mathrm{G}}(\tau) \quad$ Global cost (referred to starting year $\left.\tau_{0}\right), €$

$\mathrm{C}_{\mathrm{I}} \quad$ Initial investment costs, $€$

$\mathrm{C}_{\mathrm{a}, \mathrm{i}} \mathrm{j}$ ) Annual cost year $\mathrm{i}$ for component $\mathrm{j}$ (including running costs and periodic or replacement costs), $€$

$\mathrm{EP}_{\mathrm{H}}$ energy performance index in the heating season, $\mathrm{kWh} \mathrm{m}^{-2}$ year $^{-1}$
$\mathrm{EP}_{\mathrm{H}, \mathrm{env}}$

energy performance index in the heating season for building envelope, $\mathrm{kWh} \mathrm{m}^{-2}$ year ${ }^{-1}$

g vapour flow rate through the building element, $\mathrm{kg}$ $\mathrm{m}^{-2} \mathrm{~s}^{-1}$

h height, $\mathrm{m}$

$\mathrm{H}_{\text {tr }} \quad$ heat transfer coefficient by transmission, $\mathrm{W} \mathrm{K}^{-1}$

$\mathrm{H}_{\mathrm{D}} \quad$ direct heat transfer coefficient by transmission to the external environment, $\mathrm{W} \mathrm{K}^{-1}$

$\mathrm{H}_{\mathrm{g}} \quad$ heat transfer coefficient by transmission to the ground, $\mathrm{W} \mathrm{K}^{-1}$

$\mathrm{H}_{\mathrm{U}} \quad$ heat transfer coefficient by transmission through unconditioned spaces, $\mathrm{W} \mathrm{K}^{-1}$

$\mathrm{H}_{\mathrm{A}}$ heat transfer coefficient by transmission to adjacent zones, maintained at different temperatures, $\mathrm{W} \mathrm{K}^{-1}$

$\mathrm{H}_{\mathrm{x}} \quad$ general expression of $\mathrm{H}_{\mathrm{D}}, \mathrm{H}_{\mathrm{g}}, \mathrm{H}_{\mathrm{U}}$, or $\mathrm{H}_{\mathrm{A}}$

$l_{k} \quad$ length of the $\mathrm{k}$-linear thermal bridge, $\mathrm{m}$

$\mathrm{L}$ length, $\mathrm{m}$

$\mathrm{P}_{\mathrm{e}} \quad$ external monthly mean vapour pressure, $\mathrm{Pa}$

$\mathrm{P}_{\mathrm{i}} \quad$ internal monthly mean vapour pressure, $\mathrm{Pa}$

$\mathrm{Q}_{\mathrm{H}, \mathrm{gn}} \quad$ total heat gains for the heating mode, MJ

$\mathrm{Q}_{\mathrm{H} \text {,nd }} \quad$ building energy need for continuous heating, MJ

Qint sum of internal heat gains, MJ

$\mathrm{Q}_{\text {sol }} \quad$ sum of solar heat gains over the given period, MJ

$\mathrm{Q}_{\mathrm{tr}} \quad$ total heat transfer by transmission, MJ

$\mathrm{Q}_{\mathrm{ve}} \quad$ total heat transfer by ventilation, $\mathrm{MJ}$

$R \quad$ thermal resistance, $\mathrm{m}^{2} \mathrm{~K} \mathrm{~W}^{-1}$

$R_{d}(i) \quad$ discount rate for year $i$

$\mathrm{S}_{\mathrm{d}} \quad$ vapour diffusion-equivalent air layer thickness, $\mathrm{m}$

$\mathrm{t}$ time period, $\mathrm{s}$

$\mathrm{U}$ thermal transmittance, $\mathrm{W} \mathrm{m} \mathrm{m}^{-2} \mathrm{~K}^{-1}$

$V_{f, \tau}(j)$ final value of component $j$ at the end of the calculation period (referred to the starting year $\tau_{0}$ )

\section{Greek symbols}

$\gamma_{\mathrm{H}}$ dimensionless heat-balance ratio for the heating mode

$\delta \quad$ vapour permeability, $\mathrm{kg} \mathrm{m}^{-1} \mathrm{~s}^{-1} \mathrm{~Pa}^{-1}$

$\delta_{0} \quad$ vapour permeability of air with respect to partial vapour pressure, $\mathrm{kg} \mathrm{m} \mathrm{m}^{-1} \cdot \mathrm{s}^{-1} \cdot \mathrm{Pa}^{-1}$

$\eta_{\mathrm{H}, \mathrm{gn}} \quad$ gain utilization factor

$\theta_{\mathrm{i}} \quad$ internal temperature, ${ }^{\circ} \mathrm{C}$

$\theta_{\mathrm{e}} \quad$ external temperature, ${ }^{\circ} \mathrm{C}$

$\lambda$ thermal conductivity, $\mathrm{W} \mathrm{m}^{-1} \mathrm{~K}^{-1}$

$\mu \quad$ water vapour resistance factor

$\rho \quad$ density, $\mathrm{kg} \mathrm{m}^{-3}$

$\chi_{j} \quad$ point thermal transmittance of the $\mathrm{j}$-point thermal bridge, $\mathrm{W} \mathrm{K}^{-1}$

$\psi_{\mathrm{k}} \quad$ linear thermal transmittance of the $\mathrm{k}$-thermal bridge, $\mathrm{W} \mathrm{m}^{-1} \mathrm{~K}^{-1}$

$\tau \quad$ economic calculation period, years 